\title{
Serological and gene sequencing analysis of a case of para-Bombay phenotype $\mathrm{Am}^{\mathrm{h}}$
}

\author{
Xiaoli Li, Ruirui Su, Yuan Zhang, Xiaofei Li * \\ Beijing Friendship Hospital, Capital Medical University, Beijing 100050, China.
}

\begin{abstract}
The paper aims to study the serological and genetic characteristics of a case of para-Bombay Am ${ }^{\mathrm{h}}$. The serological method was applied to identify the proband's ABO phenotype and PCR-SSP assay was used to analyze the genotype of the para-Bombay blood. DNA sequencing of the PCR products of the first exon of FUT1 gene was used to analyze the genotype and nucleic acid sequence mutation. The serological results showed that the ABO phenotype of the proband was O-type. However, while after absorption-elution test, the ABO phenotype showed weak A-type. The serological test also showed that the irregular antibody anti-H was positive. PCR-SSP assay showed that the proband was $h 4$ para-Bombay type and sequence analysis showed a point mutation c.35C $>\mathrm{T}$ of FUT1 gene. The study suggests that genetic analysis is necessary for blood typing in those who have elusive immunological typing results.
\end{abstract}

Keywords: blood group, para-Bombay phenotype, FUT1 gene

\section{INTRODUCTION}

Para-Bombay phenotype is a rare blood group, often showing an inconsistent or unexpected $\mathrm{ABO}$ phenotype by using conventional serological techniques ${ }^{[1]}$. The underlying mechanism is as follows: $\mathrm{H}$ antigen is the precursor of $\mathrm{A}$ and $\mathrm{B}$ antigen on the surface of red blood cells (RBCs), and its synthesis depends on the activity of a-(1,2)-fucosyltransferase (FUT1). FUT1 mutation can cause the failure of $\mathrm{H}$ antigen synthesis, which can result in the defective $\mathrm{A}$ and $\mathrm{B}$ antigens ${ }^{[2]}$. Para-Bombay individuals often have anti-H antibody and show the unconformity of forward and reverse typing. If para-Bombay patients are given RBCs containing $\mathrm{H}$ antigen, they will suffer severe hemolytic reactions ${ }^{[3]}$. Here, we reported a Chinese case of para-Bombay $\mathrm{Am}^{\mathrm{h}}$ phenotype with unconformity of forward and reverse typing, caused by a disruptive mutation in FUTI of a pregnant woman. This case highlights the importance of determining blood type accurately before clinical blood transfusion for pregnant women.

\section{SUBJECTS AND METHODS}

\section{Subjects}

The proband was a 27-year-old Han female with 39 weeks gestation from Shandong Province. She had a history of one successful delivery without transfusion. The serological results showed unconformity of forward and reverse typing. Meanwhile, the irregular antibody screening results were positive and $\mathrm{Rh}$ is also positive. This study was approved by Ethics Committee in the hospital and the informed consent was ob-

*Correspondence to: Xiaofei Li, Beijing Friendship Hospital, Capital Medical University, Beijing 100050, China. E-mail: $15552889799 @ 163$. com.

The authors declared no conflict of interests. 
tained from the participant.

\section{Reagents and instruments}

Anti-A and anti-B serum (20171224, Shanghai Blood Biomedical Co., China; 8000176551, Sanquin, Amsterdam, Netherland); Anti-Le ${ }^{\mathrm{a}}$ and anti-Le ${ }^{\mathrm{b}}$ antibody (8000227742, Sanquin, Amsterdam, Netherland); Antibody screening cells (8000237560, Sanquin, Amsterdam, Netherland); Antibody identification spectrum cells (8000207012, Sanquin, Amsterdam, Netherland); Human erythroid Bombay blood group genotyping kit (PCR-SSP, Tianjin Super Biotechnology Development Co., Ltd.); Taq polymerase (Promega Company, USA); KA-2200 centrifuge (Kubota Company, Japan).

\section{Detection of ABH antigens on red blood cells}

$\mathrm{ABO}$ forward and reverse group typing of proband were determined by using the routine serological method. Further absorption and elution test was conducted to detect the trace amount of $\mathrm{ABH}$ antigens on the surface of RBCs. The secretion of ABH antigens in saliva was detected by the standard serologic hemagglutination inhibition method. Lewis blood group was also tested for identification of the secretory type.

\section{PCR-SSP genotyping}

The para-Bombay gene was detected by human erythroid Bombay blood group genotyping kit (PCRSSP). The internal control was a conserved fragment (983 bp) of $h G H$ gene. The primers's sequences were seen in Table 1. An ultraviolet gel imaging system was used to observe the results and record the image. PCR cycle parameters were: $96^{\circ} \mathrm{C}, 2 \mathrm{~min} ; 96^{\circ} \mathrm{C}, 2 \mathrm{~min}, 1$ cycle; $96^{\circ} \mathrm{C}, 20 \mathrm{sec}, 68^{\circ} \mathrm{C}, 60 \mathrm{sec}, 5$ cycles; $96^{\circ} \mathrm{C}, 20 \mathrm{sec}$, $65^{\circ} \mathrm{C}, 45 \mathrm{sec}, 72^{\circ} \mathrm{C}, 30 \mathrm{sec}, 10$ cycles; $96^{\circ} \mathrm{C}, 20 \mathrm{sec}$, $62^{\circ} \mathrm{C}, 45 \mathrm{sec}, 72^{\circ} \mathrm{C}, 30 \mathrm{sec}, 15$ cycles; $72^{\circ} \mathrm{C}, 2 \mathrm{~min}$, 1 cycle; $4{ }^{\circ} \mathrm{C}$ preserved.

\section{FUT1 and ABO gene sequencing}

The FUTI and ABO gene EXONI-7 were directly
Table 1 The primers sequences of the eight holes and the names of genes

\begin{tabular}{|c|c|c|c|}
\hline Position & Direction & Primers & Sequences $\left(5^{\prime}-3^{\prime}\right)$ \\
\hline \multirow[t]{2}{*}{1} & forward & hl & TCGTGCAGGGTGAAGTCTGC \\
\hline & reverse & $\mathrm{Nh} 4$ & ATCGTCAGCTCTGCGTGGC \\
\hline \multirow[t]{2}{*}{2} & forward & $\mathrm{Nhl}$ & GTCGTGCAGGGTGAAGTCTCT \\
\hline & reverse & $\mathrm{Nh} 4$ & ATCGTCAGCTCTGCGTGGC \\
\hline \multirow[t]{2}{*}{3} & forward & h2 & GCACTGTGTGAGCAGGGGAG \\
\hline & reverse & $682 \mathrm{~A}$ & CGTGGGGACTATCTGCAGGTTA \\
\hline \multirow[t]{2}{*}{4} & forward & Nh2 & GCACTGTGTGAGCAGGGGAA \\
\hline & reverse & $682 \mathrm{~A}$ & CGTGGGGACTATCTGCAGGGTA \\
\hline \multirow[t]{2}{*}{5} & forward & h3 & TGTCGGCGTCCACGGGT \\
\hline & reverse & Nh2 & GCACTGTGTGAGCAGGGGAA \\
\hline \multirow[t]{2}{*}{6} & forward & $\mathrm{Nh} 2$ & GCACTGTGTGAGCAGGGGAA \\
\hline & reverse & Nh3 & TGTCGGCGTCCACGGGC \\
\hline \multirow[t]{2}{*}{7} & forward & $682 \mathrm{G}$ & GTGGGGACTATCTGCAGGGTG \\
\hline & reverse & $\mathrm{Nh} 2$ & GCACTGTGTGAGCAGGGGAA \\
\hline \multirow[t]{2}{*}{8} & forward & Nhl & GTCGTGCAGGGTGAACTGTCT \\
\hline & reverse & h4 & ATCGTCAGCTCTGCGTGGT \\
\hline
\end{tabular}

sequenced. The FUTI gene primer sequences: forward, 5'-CTGGGACTAAGGAGTCTGC-3'; reverse, 5'-CTGCCTGCCAGGCATC-3'. PCR products were sequenced using a cycle sequencing kit on ABI 3730 sequencer. The mutation site was determined by BLAST with existing exonl sequence in GenBank.

\section{RESULTS}

\section{Serological identification}

The testing of the patient's RBCs with monoclonal $A B O$ typing reagents indicated that the blood type of the proband was weak A type, but easily confused with O phenotype. During reverse blood group typing at room temperature, the serum was strongly reactive with Bc RBCs with 4+ intensity of agglutination, and weakly reactive with $\mathrm{Al}$ and $\mathrm{O}$ cells. However, reverse typing showed the presence of anti-Al $(2+)$ and $\mathrm{O}$ cells at $4^{\circ} \mathrm{C}$, and the presence of anti-Al $(1+)$ and $\mathrm{O}$ cells at $37^{\circ} \mathrm{C}$ (Table 2$)$.

Table 2 Serological results of blood group typing

\begin{tabular}{|c|c|c|c|c|c|c|c|c|c|}
\hline \multirow{2}{*}{ Reaction temperature } & \multicolumn{5}{|c|}{ Antigen on RBCs } & \multicolumn{4}{|c|}{ Antibody in serum } \\
\hline & anti-A & anti-B & anti-H & anti-Le $^{\mathrm{a}}$ & anti-Le $^{\mathrm{b}}$ & Alc & $\mathrm{Bc}$ & Oc & Control \\
\hline $4^{\circ} \mathrm{C}$ & 0 & 0 & 0 & 0 & $2+$ & $2+$ & $4+$ & $2+$ & 0 \\
\hline Room temperature & 0 & 0 & 0 & 0 & $1+$ & $1+$ & $4+$ & $1+$ & 0 \\
\hline $37^{\circ} \mathrm{C}$ & 0 & 0 & 0 & 0 & $1+$ & $1+$ & $4+$ & $1+$ & 0 \\
\hline
\end{tabular}

Note: ABO forward and reverse typing and Lewis type. Antigen typing using monoclonal reagents showed generally negative results $(0)$, as opposed to positive reactions (slightly positive $1+\sim 2+$, and strongest positive $3+\sim 4+$, respectively). 


\section{Absorption-elution test, saliva-test and anti- body identification}

The absorption-elution test of proband showed weak reaction with $\mathrm{Ac}(2+)$. The presence of $\mathrm{ABH}$ substances in saliva was consistent with their Le (ab+) phenotypes (Table 3). Anti-H was found in the serum of individual with titer of 1:32.

Table 3 Absorption-elution test and saliva test results

\begin{tabular}{lccccccc}
\hline Contents & \multicolumn{3}{c}{ Absorption-elution test } & & \multicolumn{3}{c}{ Saliva test } \\
\cline { 2 - 3 } \cline { 6 - 7 } Reagents & $\mathrm{Ac}$ & $\mathrm{Bc}$ & Control & & Anti-A & Anti-B & Anti-H \\
\hline Reaction & $2+$ & 0 & 0 & & 0 & $2+$ & 0 \\
Conclusion & \multicolumn{3}{c}{ Weak A antigen } & & A and H substance positive \\
\hline
\end{tabular}

\section{PCR-SSP genotyping}

According to the base number of the target gene involved in the study, there are $241 \mathrm{bp}, 264 \mathrm{bp}$, and 541 bp bands respectively at the 4,6 , and 8 in the classification table of reference gene results, which is confirmed as $h 4$ homozygotes, as shown in Fig. 1.

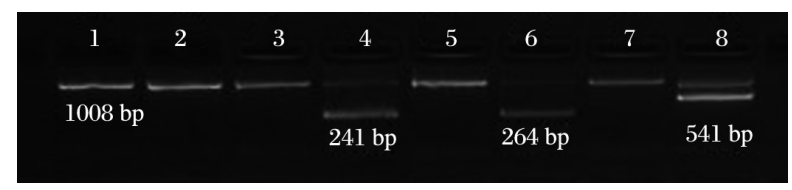

Fig. 1 PCR-SSP genotyping results

\section{Gene sequencing}

The direct sequencing analysis of FUTI PCR products showed that the point mutation at the $35^{\text {th }}$ base was c. $35 \mathrm{C}>\mathrm{T}$ (Fig. 2). The sequencing results were consistent with the results of genotyping method. And the $\mathrm{ABO}$ sequencing was $\mathrm{ABO} * \mathrm{~A} 1.02 / \mathrm{ABO} * \mathrm{O} .02 .01$.

$\begin{array}{llllllllllllllllll}G & C & C & T & G & G & \text { I } & C & T & T & C & C & T & G & C & T & A\end{array}$

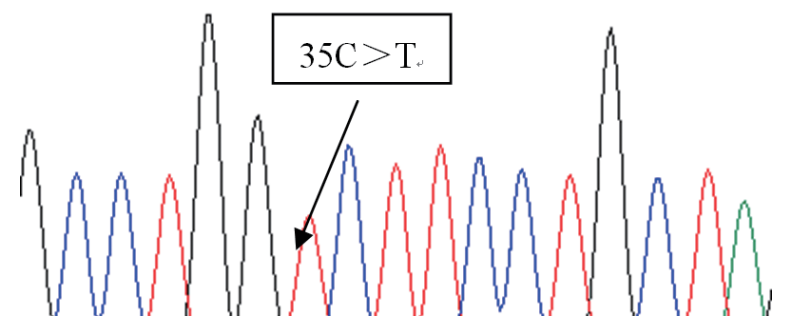

Fig. 2 Sequence analysis results of FUT1 gene

\section{DISCUSSION}

The para-Bombay phenotype is characterized by the absence or weak expression of $\mathrm{ABH}$ antigens on $\mathrm{RBCs}$, with the presence of $\mathrm{ABH}$ substances in body secretions ${ }^{[1,4]}$. In this study, one individual with the
para-Bombay $\mathrm{Am}^{\mathrm{h}}$ phenotype was detected. Unfortunately, her previous blood transfusion history was not known, and any family related data were not available. Anti-H antibody was observed in the patient's serum and still active at $37^{\circ} \mathrm{C}$. The presence of anti-H antibody has clinical significance, since it can activate complement and cause hemolysis ${ }^{[5-8]}$. Therefore, when an individual with para-Bombay requires transfusion, it is necessary to use RBCs without $\mathrm{H}$ antigen. The para-Bombay $A m^{\mathrm{h}}$ phenotype is easily confused with $\mathrm{O}$ phenotype. So absorption-elution test combined with genotyping is necessary for this kind of blood group typing.

At present, there are more than 50 reported mutations in FUTl gene, including missense, deletion, and insertion mutations. The most common mutations are the following: $h l$ (547delAG), $h 2$ (880delTT) and $h 3(658 \mathrm{C}>\mathrm{T})^{[9]}$. The genes of both Bombay type and para-Bombay type are polymorphic ${ }^{[10]}$. Most of the mutations are point mutations, or gene deletions at different position ${ }^{[11]}$. In our study, the para-Bombay PCR-SSP kit was selected to confirm the paraBombay genotype. So far, nearly 50 different FUT1 mutations capable of causing $\mathrm{H}$ antigen defects in RBCs have been reported ${ }^{[12-14]}$. The proband we found was $h 4 / h 4$ genotype. The molecular basis of mutation in FUT1 was c. $35 \mathrm{C}>\mathrm{T}$. This mutation brings to the amino acid change of $\alpha$-(1,2)-fucosyltransferase from alanine (ALA) to valine (VAL), which would result in the termination of protein synthesis. The mutation caused the loss or decline of the enzyme activity and the para-Bombay serological panel emerged.

In this paper, we only observed the mutations of FUT1 and the ABO genes, but failed to analyze FUT2 gene. And it is necessary to study the family investigation in the future.

\section{Acknowledgements and funding}

This work was supported by the grants of National Natural Science Foundation of China (grant No. 81770194) and the Digestive Medical Coordinated Development Center of Beijing Hospital Authority (grant No. XXX0108).

\section{References}

[1] Lin JJ, Chen RC, Zhu SY, et al. Sequence analysis of $\alpha-(1$, 2)-fucosyltransferase gene in nine Chinese individuals with para-Bombay phenotype[J]. Gene, 2019, 685: 21-3.

[2] Yang XJ, Xie HH, Peng YX. Identification and transfusion strategy of Bombay like type[J]. Chinese Journal of Blood Transfusion (in Chinese), 2018, 31(5): 486-9.

[3] Luo GP, Wei L, Wang Z, et al. The summary of FUT1 and FUT2 genotyping analysis in Chinese para-Bombay 
individuals including additional nine probands from Guangzhou in China[J]. Transfusion, 2013, 53: 3224-9.

[4] Zhao Q, Wang ZL, Su M, et al. Identification and molecular mechanism of para-Bombay phenotype[J]. J Clin Hematol (in Chinese), 2019, 32(1): 159-61.

[5] Zhang JP, Zheng Y, Sun DN, et al. Formation of paraBombay phenotype caused by heterozygous or homozygous mutations of FUT1 gene[J]. Chinese Journal of Experimental Hematology (in Chinese), 2014, 22(1): 195-8.

[6] Liao XC, Jiao W, Li HL, et al. Molecular mechanism of para-Bombay: a report of 2 families[J]. Chinese Journal of Blood Transfusion (in Chinese), 2015, 28(12): 1475-8.

[7] Wang F, Mao W, Zhang T, et al. Study on the molecular mechanism of Bh para-Bombay[J]. Chinese Experimental Diagnostics (in Chinese), 2017, 21(7): 1249-52.

[8] Chang HJ, Zhang NH. Serological characteristics and pedigree analysis of a para-Bombay[J]. Journal of Clinical Transfusion and Laboratory Medicine (in Chinese), 2018, 20(5): 556-7.

[9] Guo ZH, Xiang D, ZhuZY, et al. Analysis on FUT1 and
FUT2 gene of 10 para-Bombay individuals in China[J]. Chin J Med Genet (in Chinese), 2004, 21(5): 417-21.

[10] Wang Ni, Song WQ, Xia YX, et al. Gene analysis of a Bmhpara-Bombay[J]. Chinese Journal of Blood Transfusion (in Chinese), 2019, 32(8): 828-30.

[11] Matzhold EM, Wagner T, Drexler C, et al. FUT1 aberrant $\mathrm{ABO} B$ phenotype with irregular anti-B caused by a para-Bombay mutation[J]. Transfus Med Hemother, 2020, 47: 94-7.

[12] Yang XY, Wang GY. Advances in ABO gene expression regulation[J]. Asia-Pacific Journal of Blood Types and Genes, 2019, 3(2): 101-7.

[13] Er TK, Yang TC, Liu YH. Heterozygous FUT1 mutations causing a para-Bombay phenotype[J]. Clin Lab, 2018, 64: 1787-9.

[14] Liang W, Cai F, Yang L, et al. FUT1 four non-functional alleles were identified in seven Chinese individuals with para-Bombay phenotypes[J]. Iran J Public Health, 2018, 47: 1128-36.

Received 4 March 2020, Revised 31 March 2020, Accepted 31 May 2020 